\title{
MENINGKATKAN HASIL BELAJAR SISWA DENGAN METODE DISKUSI KELOMPOK MATERI AKHLAK TERPUJI KELAS II-B MIN PAYA BUJOK TAHUN 2015/2016
}

\section{Oleh :Rahmawati H,S.Pd.I}

\begin{abstract}
ABSTRAK
Didalam proses belajar mengajar kadang kala guru masih kurang menggunakan metode yang sangat tepat. Pelajaran yang diberikan oleh guru secara langsung, seharusnya dapat diamati, diteliti, di hayati dan dikerjakan sendiri oleh anak didik, sehingga dapat menimbulkan kesan yang lebih lama dan tidak mudah terlupakan. Oleh karena itu media pendidikan memegang peranan penting dalam menunjang keberhasilan proses belajar mengajar. Metode diskusi kelompok adalah merupakan salah satu metode pembelajaran yang bisa membuat siswa lebih aktif dan berpartisipasi dalam proses belajar mengajar. Dalam pembelajaran ini guru memberikan pengarahan dan bimbingan sesuai dengan materi yang akan di ajarkan kepada sisiwa, yang mana siswa disuruh berdiskusi langsung kepada teman dan kelompoknya. Pendekatan yang digunakan dalam penelitian ini adalah pendekatan kualitatif dan jenis penelitiannya adalah penelitian tindakan kelas yang terdiri atas 2 siklus dan setiap satu siklus dua kali pertemuan. Subjek penelitian adalah siswa kelas II-b pada MIN Paya Bujok yang berjumlah 36 siswa. Analisis data menggunakan teknik analisis deskriptif komparatif dengan membandingkan kondisi awal dengan hasil-hasil yang dicapai pada setiap siklus dan analisis deskriptif kualitatif hasil observasi dan refleksi pada siklus I dan siklus II. Berdasarkan hasil penelitian diperoleh peningkatan ketuntasan belajar siswa dalam siklus I yaitu 8 siswa atau 23,53. Selanjutnya pada siklus II diperoleh hasil yang memuaskan karena 29 siswa atau $85.29 \%$ berhasil mendapatkan nilai diatas KKM 70, selebihnya masih ada 5 siswa atau 14.17\% yang tidak tuntas. Maka dapat disimpulkan adanya peningkatan hasil belajar siswa pada materi Akhlak Terpuji menggunakan metode diskusi pada siswa
\end{abstract}

Keyword: metode diskusi kelompok, Akhlak Terpuji

AT-TARBAWI Media Pendidikan, Sosial dan Kebudayaan 


\section{A. Pendahuluan}

Mata pelajaran Akidah akhlak dianggap sebagai pelajaran yang mudah dipelajari. Pada dasarnya pelajaran Akidah Akhlak termasuk pelajaran yang sulit, karena menyentuh pada perobahan prilaku peserta didik yamg tidak santun keprilaku yang lebih santun, sehingga mempengaruri hasil belajar, dan hasil yang diperoleh sangat jauh dari yang diharapkan. Sebagai gambaran dari hasil ulangan harian materi sebelumnya siswa yang memperolah nilai di bawah standar ketuntasan yang telah di tetapkan oleh pihak sekolah, hampir rata-rata nilai yang di peroleh siswa pada materi akhlak terpuji masih sangat rendah di bawah standar kelulusan.

Penyebab kesulitan belajar yang dihadapi siswa sangatlah komplek, yang salah satunya disebabkan oleh guru misalnya, guru dalam proses pembelajaran tidak mengikutsertakan siswa dalam pembelajaran secara aktif, siswa hanya disuruh menghafal Kosa kata, menerima konsepkonsep yang ada tidak melakukan sendiri. Sehingga hasilnya kurang bermakna dan tidak terekam dengan baik pada otak siswa.

Untuk meningkatkan hasil belajar sisiwa tersebut, peneliti menerapkan metode diskusi kelompok dalam pelajaran akidah akhlak materi akhlak terpuji. Pemilihan metode pembelajarn bervariasi di harapkan bisa meningkatkan hasil belajar siswa dalam materi tersebut

Oleh karena itu, peneliti mengajukan penelitian dengan judul Meningkatkan Hasil Belajar siswa dengan menggunakan metode dskusi kelompok Materi Akblak Terpuji Kelas 2-B MIN Paya Bujok Langsa Tabun 2015.

Berdasarkan latar belakang masalah yang diuraikan sebelumnya, rumusan masalah dalam penelitian ini sebagai berikut: Apakah Metode diskusi kelompok dapat meningkatkan hasil belajar siswa pada materi akhlak terpuji kelas 2-b MIN Paya Bujok Langsa.

Sesuai dengan permasalahan di atas, penelitian ini bertujuan ingin mengetahui penggunaan metode diskusi kelompok dapat meningkatkan hasil belajar siswa materi akhlak terpuji pada siswa kelas 2-b MIN Paya Bujok.

Adapun manfaat penelitian yang diharapkan dari penelitian ini adalah sebagai berikut:

1. Bagi siswa : Dengan pembelajaran yang menyenangkan siswa bergairah belajar sehingga hasil belajar meningkat dan membangkitkan minat siswa untuk mempelajari akidah akhlak.

2. Bagi guru bidang studi : sebagai sarana untuk meningkatkan hasil proses mengajar bidang studi akidah akhlak. 
3. Bagi Kepala Sekolah : sebagai sarana pembinaan kepada guru-guru akidah Akhlak untuk mempertimbangkkan penggunaan metode teknik diskusi.

\section{B. Landasan Teori}

\section{Pelajaran Aqidah di MI}

Mata pelajaran Aqidah Akhlak berfungsi untuk memberikan pengetahuan dan bimbingan kepada siswa agar menghayati dan meyakini rukun iman serta menjadikannya sebagai landasan perilaku dalam kehidupan sehari-hari dalam hubungan dengan Tuhannya, sesama manusia dan dengan alam sekitar. Di MI, bahan pelajaran Aqidah Akhlak ditekankan pada pemberian pengetahuan dan pemahaman rukun iman dengan sederhana serta pengalaman dan pembiasaan akhlak Islam yang sederhana untuk dapat diamalkan dalam kehidupan sehari-hari dan dapat dijadikan bekal untuk pendidikan berikutnya ${ }^{1}$

\section{Hakekat Belajar}

Ada beberapa pendapat tentang belajar yaitu :2

a. Robert Gane berpendapat bahwa belajar harus didasarkan kepada pandangan bahwa tahap belajar yang lebih tinggi berdasarkan atas tahap belajar yang lebih rendah.

b. J. Bruner berpendapat bahwa belajar ialah belajar tentang konsep-konsep dan struktur yang terdapat dalam materi yang dipelajari serta mencari hubungan antara konsep konsep dan struktur-struktur.

c. Z.P Dienes berpendapat bahwa setiap konsep atau prinsip dapat dimengerti secara sempurna hanya jika pertama-tama disajikan kepada siswa dalam bentuk konkrit.

d. Sedangkan menurut Aussebel, bahan pelajaran yang dipelajari harus bermakna, artinya bahan pelajaran itu cocok dengan kemampuan siswa harus sesuai dengan struktur koginitif yang dimiliki siswa. Denga kata lain pelajaran baru harus dikaitkan dengan konsep-konsep yang sudah ada sedemikian sehingga konsep-konsep yang sudah sedemikian sehingga konsep-konsep itu benar-benar terserap.

1. Departemen Agama RI/Direktorat Jendral, Pembinaan Kelembagaan Islam, hal.286-287

2. Eman Suherman dan Udin S.Winatapura, Materi Pokok Strategi Mengajar, 
e. Menurut Gagne (1984), belajar dapat didefenisikan sebagai suatu proses di mana suatu organisasi berubah perilakunya sebagai akibat pengalaman.(Prof.Dr.Ratna Wilis Dahar,M.Sc,(2006:2)

\section{Prestasi belajar}

Apa yang dimaksud dengan Prestasi Belajar? Sebelum dijelaskan mengenai prestasi belajar, terlebih dahulu akan dikemukakan tentang pengertian prestasi. Sudah dijelaskan dimuka bahwa yang dimaksud dengan prestasi adalah hasil baik yang telah dicapai. Dengan demikian prestasi adalah hasil yang telah dicapai oleh seseorang setelah melakukan suatu pekerjaan / aktivitas tertentu. Jadi prestasi adalah hasil yang telah dicapai oleh karena itu semua individu dengan adanya belajar hasilnya dapat dicapai. Setiap individu menginginkan hasil yang sebaik mungkin. Oleh karena itu setiap individu harus belajar dengan sebaik- baiknya supaya prestasinya berhasil dengan baik.

Pengertian dari dua kata prestasi dan belajar atau prestasi belajar berarti hasil belajar, secara lebih khusus setelah siswa mengikuti pelajaran dalam kurun waktu tertentu. Berdasarkan penilaian yang dilaksanakan guru di sekolah, maka prestasi belajar dituangkan atau diwujudkan dalam bentuk angka (kuantitatif) dan pernyataan verbal (kualitatif). Prestasi belajar yang dituangkan dalam bentuk angka misalnya 10, 9, 8, dan seterusnya. Sedangkan prestasi belajar yang dituangkan dalam bentuk pernyataan verbal misalnya, baik sekali, baik, sedang, kurang, dan sebagainya.

Menurut the Liang Gia Mengatakan bahwa: Prestasi belajar adalah hasil yang dicapai aktifitas yang menghasilkan perubahan-perubahan tingkah laku dalam individu, baik secara aktual maupun profesional ". 3

Sedangkan Purwodarminto mengatakan bahwa : " prestasi belajar adalah suatu hasil yang dicapai atau dikerjakan siswa dalam belajar atau usaha untuk memperoleh suatu kepandaian ".4

Belajar sangat erat hubungannya dengan prestasi belajar.Karena prestasi itu sendiri merupakan hasil belajar itu biasanya dinyatakan dengan nilai. Menurut Winarno Surahmad (1997 : 88) sebagai berikut: "Hasil belajar adalah hasil dimana guru melihat bentuk akhir dari pengalaman interaksi edukatif yang diperhatikan adalah

3. Holstein, Murid Belajar Mandiri, (Bandung :Remaja Karya, 1989), hal. 15

4. I.G.A,K. Wardani, Kuswaya W, Noehi Nasoetion, Penelitian Tindakan Kelas, (Jakarta :Universitas Terbuka,1987) hal. 254 
menempatkan tingkah laku". Dapat diartikan bahwa hasil belajar adalah suatu bentuk pertumbuhan atau Perubahan diri seseorang yang dinyatakan dengan cara bertingkah laku baru berkat pengalaman baru.

Dari pengertian tersebut diatas dapat disimpulkan, bahwa prestasi belajar adalah suatu hasil belajar yang dicapai dalam aktifitas untuk mendapat suatu kepandaian atau sebuah tingkah laku yang lebih baik.

Untuk memperoleh prestasi belajar atau hasil belajar yang baik harus dilakukan dengan pedoman cara yang tepat. Setiap orang mempunyai cara atau pedoman sendiri-sendiri dalam belajar. Pedoman atau cara yang satu cocok digunakan oleh seorang siswa, tetapi belum tentu cocok untuk siswa yang lain. Hal ini disebabkan karena mempunyai perbedaan individu dalam hal kemampuan, kecepatan dan kepekaan dalam menerima materi pelajaran. Oleh karena itu tidaklah ada suatu petunjuk yang pasti yang harus dikerjakan oleh seorang siswa dalam melakukan kegiatan belajar. Tetapi faktor yang paling menentukan keberhasilan belajar adalah para siswa itu sendiri. Untuk dapat mencapai hasil belajar yang sebaik- baiknya harus mempunyai kebiasaan belajar yang baik.

Banyak sekali faktor- faktor yang mempengaruhi prestasi belajar telah dikatakan dimuka bahwa belajar adalah berusaha memperoleh kepandaian, ilmu pengetahuan. Sampai dimanakah perubahan itu dapat dicapai atau dengan kata lain dapat berhasil baik atau tidaknya belajar itu tergantung pada macam- macam faktor. Adapun faktor- faktor itu, dapat dibedakan menjadi dua golongan yaitu: 1) Faktor yang ada pada diri siswa itu sendiri yang kita sebut faktor individu. 2) Faktor yang ada pada luar individu yang kita sebut dengan faktor sosial.

Berdasarkan faktor yang mempengaruhi kegiatan belajar di atas menunjukkan bahwa belajar itu merupakan proses yang cukup kompleks. Aktivitas balajar individu memang tidak selamanya menguntungkan. Kadang- kadang juga tidak lancar, kadang mudah menangkap apa yang dipelajari, kadang sulit mencerna materi pelajaran. Dalam keadaan dimana anak didik atau siswa dapat belajar sebagaimana mestinya, itulah yang disebut kesulitan belajar. Dalam kondisi Seperti itu maka di perlukan metode atau starategi belajar untuk mencapai prestasi belajar yang maksimal.

\section{Pengertian Hasil Belajar}

Untuk mengetahui sejauh mana proses belajar mengajar mencapai tujuan pembelajaran yang diharapkan, maka perlu diadakan tes hasil belajar. Menurut pendapat 
Winata Putra dan Rosita ${ }^{5}$ tes hasil belajar adalah salah satu alat ukur yang paling banyak digunakan untuk menentukan keberhasilan seseorang dalam suatu proses belajar mengajar atau untuk menentukan keberhasilan suatu program pendidikan.

Adapun dasar-dasar penyususan tes hasil belajar adalah sebagai berikut:

a) Tes hasil belajar harus dapat mengukur apa-apa yang dipelajari dalam proses pembelajaran sesuai dengan tujuan instruksional yang tercantum dalam kurikulum yang berlaku.

b) Tes hasil belajar disusun sedemikian sehingga benar-benar mewakili bahan yang telah dipelajari.

c) Bentuk pertanyaan tes hasil belajar hendaknya disesuaikan dengan aspek-aspek tingkat belajar yang diharapkan.

d) Tes hasil belajar hendaknya dapat digunakan untuk memperbaiki proses belajar mengajar.

A. Tabrani ${ }^{6}$ mengatakan bahwa belajar mengajar adalah suatu proses yang rumit karena tidak sekedar menyerap informasi dari guru, tetapi melibatkan berbagai kegiatan maupun tindakan yang harus dilakukan, terutama bila diinginkan hasil yang lebih baik .

\section{Metode Pembelajaran}

Metode merupakan salah satu "sub-system" dalam "sistem pembelajaran", yang tidak bisa dilepaskan begitu saja. Metode adalah cara yang dianggap efisien yang digunakan oleh guru dalam menyampaikan suatu mata pelajaran tertentu kepada siswa-siswa agar tujuan yang telah dirumuskan sebelumnya dalam proses kegiatan pembelajaran dapat tercapai dengan efektif. Setiap mata pelajaran mempunyai metode tertentu sesuai dengan kekhususan mata pelajaran tersebut. Oleh sebab itu guru hendaknya dapat menentukan metode apa yang paling efisien bagi mata pelajarannya sehingga tujuan pengajaran tercapai secara maksimal dan efektif. Metode pembelajaran merupakan salah satu cara yang digunakan dalam mengajar. Penggunaan sebuah metode mengajar harus tepat, efisien dan efektif, sehingga siswa dapat menerima, memahami, menguasai, dan mengembangkan bahan pelajaran.

5. Syaodih, Nana, Metode Penelitian Pendidikan, (Bandung :Rosda, 2005), hal.191

6. Sunardi, Mengakrabkan Agama pada Anak, (Yogyakarta:Kedaulatan Rakyat, 2006), hal. 3. 


\section{Pengertian Pembelajaran Diskusi Kelompok}

Metode diskusi kelompok adalah suatu cara mengajar yang dicirikan oleh suatu keterikatan pada suatu topik atau pokok pernyataan atau problem dimana para peserta diskusi dengan jujur berusaha untuk mencapai atau memperoleh suatu keputusan atau pendapat yang disepakati bersama, yang merupakan salah satu bentuk pembelajaran yang menganut teori konstruktivisme. Menurut teori belajar konstruktivisme, dalam proses perolehan pengetahuan, siswa harus mengkonstruksi sendiri pengetahuan-pengetahuan itu melalui interaksi antara siswa dengan siswa lain dan siswa dengan guru. Coob dalam Malon dan Taylor menyatakan bahwa "Tradisi konstruktivisme tidak hanya sebagai aktivitas individu tetapi sebagai interaksi satu dengan yang lain, berupa interaksi dalam kelas. Ketika siswa memperhatikan penyelesaian siswa lain dan berusaha menggunakannya, serta mempertanyakannya, maka kemampuan untuk merefleksi serta menyusun kembali pemahaman menjadi meningkat, akibatnya belajar menjadi bermakna.

Metode diskusi kelompok yang menekankan pada interaksi antara siswa dengan orang lain diskusi kelompok merupakan metode belajar dimana siswa belajar dalam kelompok kecil, saling membantu untuk memahami suatu bahan pembelajaran, memeriksa dan memperbaiki jawaban teman, serta kegiatan lainnya dengan tujuan untuk mencapai prestasi belajar yang gemilang. Nur ${ }^{7}$ berpendapat bahwa :

Pembelajar diskusi kelompok yaitu pembelajaran yang melibatkan unsur-unsur siswa itu sendiri, sehingga siswa dapatr berinteraksi dalam menyelesaikan tugas-tugas yang sulit. Pembelajaran diskusi kelompok merupakan cara proses belajar siswa yang dalam satu kelompok setiap individu saling membantu terhadap yang lain dalam kelompoknya sehingga tercapai tujuan bersama.

Berkaitan dengan hal tersebut Misbah ${ }^{8}$ berpendapat bahwa "Dalam pembelajaran diskusi kelompok terdiri dari 5 sampai 20 orang dengan jenis kelamin yang berbeda, tingkat kemampuan yang berbeda pula. Siswa dapat menerima informasi dengan cepat bila melakukan sendiri secara langsung".

Ada beberapa hal yang perlu dipenuhi dalam metode diskusi kelompok agar lebih menjamin para siswa belajar secara aktif. Hal tersebut meliputi :

8. Wagiman, Setiyandoko, dkk, Belajar dan Bermain untuk SD/MI Kelas 5, (Malang: Universitas Negeri Malang, 2005), hal. 24 
a. Para siswa yang bergabung dalam suatu kelompok harus merasa bahwa mereka adalah bagian dari sebuah team yang mempunyai tujuan bersama yang harus dicapai.

b. Para siswa yang bergabung dalam suatu kelompok harus menyadari bahwa masalah yang mereka hadapi adalah masalah kelompok dan akan menjadi tanggung jawab bersama oleh seluruh anggota itu.

c. Untuk mencapai hal yang maksimum para siswa bergabung dalam kelompok itu harus berbicara satu sama lain dalam mendiskusikan masalah yang dihadapi bahwa setiap pekerjaan siswa mempunyai akibat langsung kepada keberhasilan

kelompoknya.

Strategi ini merupakan strategi yang menarik untuk digunakan jika materi yang akan dipelajari dapat dibagi menjadi beberapa bagian dan materi tersebut tidak mengharuskan urutan penyampaian.

Kelebihan strategi ini adalah dapat melibatkan seluruh peserta didik dalam belajar dan sekaligus mengajarkan kepada orang lain.

Langkah-langkah:

6. Bagi kelas menjadi 5 kelompok (masing-masing terdiri dari 6 orang) untuk lima bagian pelajaran yang berbeda, langsung untuk mendiskusikan dan menyelesaikannya tanpa harus menerangkan terlebih dahulu

7. Dari kelima kelompok dipecah kembali menjadi enam kelompok dengan anggota berbeda.

8. Setiap anggota kelompok baru menerangkan hasilnya kepada anggota lain (dalam satu kelompok) secara berurutan sampai semua kebagian.

9. Berikan 5 soal berbeda dari lima bagian pelajaran untuk diselesaikan oleh grup baru.

10. Berikan jawaban yang benar oleh guru melalui tunjuk kerja hasil diskusi untuk menerangkan hasil kerjanya di papan tulis.

\section{Pembahasan}

Penelitian tindakan kelas ini menggunakan rancangan penelitian tindakan yang

dilaksanakan di kelas, sehingga disebut Penelitian Tindakan Kelas (PTK). Penelitian ini terdiri dari 2 siklus masing-masing siklus meliputi : perencanaan, tindakan, pengamatan dan refleksi. Secara Skematis uraian digambarkan kerangka pemikirannya sebagai berikut: 


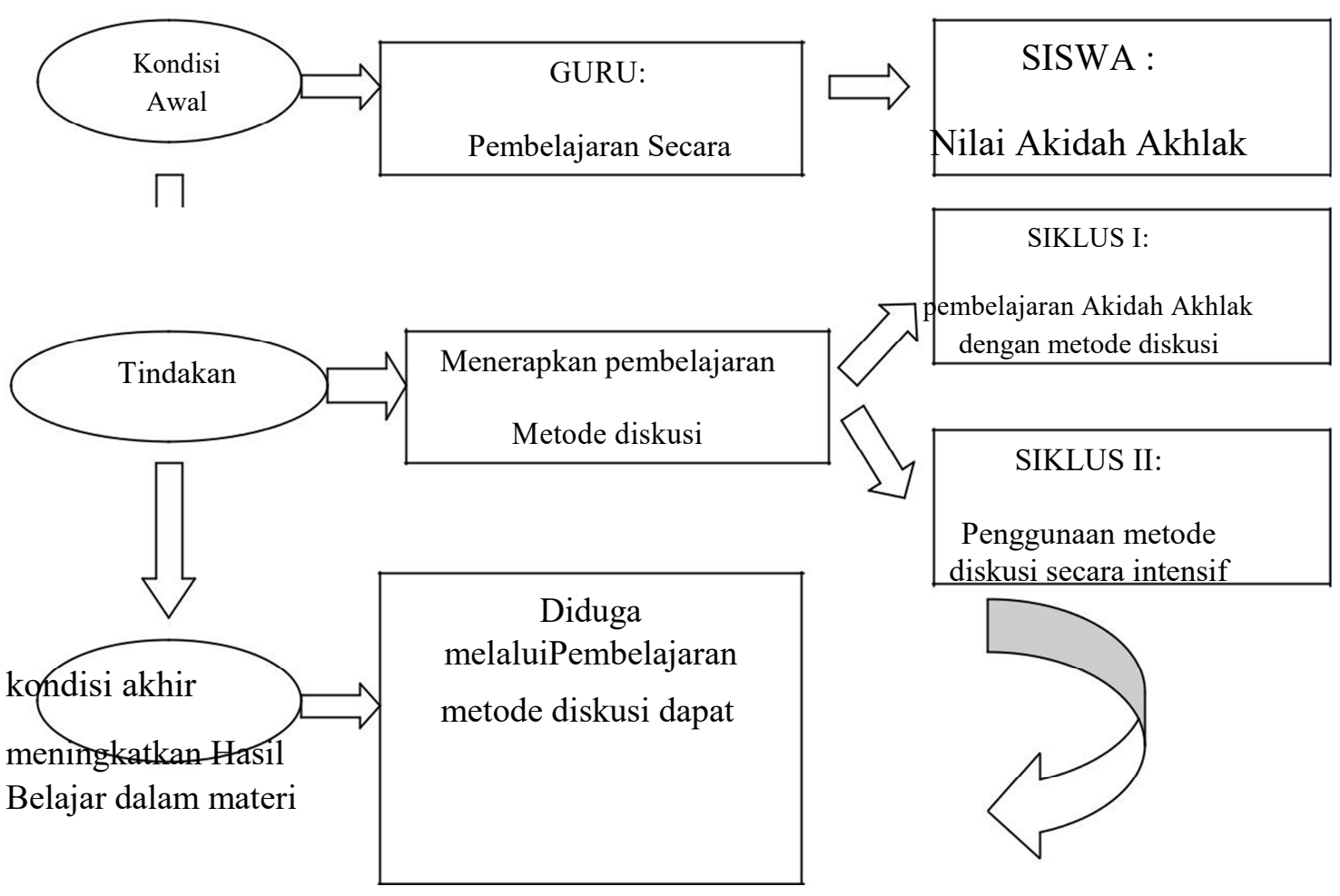

Gambar 2. Diagram alur Penelitian Tindakan Kelas

Penulis berkeyakinan bahwa metode diskusi mampu meningkatkan hasil belajar siswa kelas 2-b MIN Paya Bujok terutama pada materi Akhlak Terpuji.

Penelitian ini akan dilaksanakan di kelas II-B MIN Paya Bujok Tahun 2015, dengan alasan penulis merupakan guru aktif dan bertanggung jawab atas pembelajaran akidah akhlak.

Penelitian ini dilaksanakan selama tiga bulan, mulai awal September s/d November Tahun ajaran 2015-2016 yaitu pada semester I. Penentuan waktu disesuaikan dengan hari efektif dikelas II-b karena penelitian ini diadakan dalam 2 siklus, setiap siklus dua kali pertemuan. Pertemuan pertama pada siklus 1 akan di lakukan pada tanggal 3 September 2015 dan pertemuan kedua di siklus I akan di laksanakan pada tanggal 10 September 2015, hasil siklus I pada pertemuan pertama dan kedua akan menjadi bahan masukan pada siklus

II. Siklus II akan dilaksanakan dua kali pertemuan, pertemuan pertama akan di laksanakan pada tanggal 17 September 2015 dan pertemuan ke dua siklus ke II akan dilaksanakan pada tanggal 1 Oktober 2015. 
Subyek penelitian adalah siswa kelas II-b, sejumlah 36 orang terdiri dari berbagai macam status sosial.

Sumber data dalam penelitian ini adalah siswa, sebagai subjek penelitian. Data yang dikumpulkan dari siswa meliputi data hasil tes tertulis. Tes tertulis dilaksanakan pada setiap hari akhir siklus. Selain siswa sebagai sumber data, penulis juga ditemani teman sejawat sesama guru sebagai kalaborator:

a. Tes

Dalam penelitian ini pengumpulan data menggunakan teknik tes dan non tes. Tes tertulis digunakan pada akhir siklus I dan siklus II.

b. Observasi

Teknik non tes meliputi teknik observasi dan dokumentasi. Observasi digunakan pada saat pelaksanaan penelitian tindakan kelas. Kemampuan memahami materi Akhlak Terpuji pada siklus I, II. Sedangkan Teknik Dokumentasi dikumpulkan dari hasil kerajinan siswa.

Alat pengumpulan data meliputi :

1. Instrumen Tes secara tertulis terdiri dari 5 butir soal

2. Observasi meliputi lembar observasi dan dokumen siswa.

Validasi data meliputi validasi hasil belajar dan validasi proses pembelajaran.

1. Validasi Hasil Belajar (Nilai Tes)

Validasi hasil belajar dikenakan pada instrumen penelitian yang berupa tes. Validasi ini meliputi validasi teoritis dan validasi empiris. Validasi teoretis artinya mengadakan analisis instrumen yang terdiri atas face validity (tampilan tes), content validty (validitas isi). Validitas empiris artinya analisis terhadap butir-butir tes, yang dimulai dari perbuatan kisi-kisi soal, penulisan butir-butir soal, kunci jawaban.

2. Validasi proses pembelajaran

Validasi proses pembelajaran dilakukan dengan teknik triangulasi yang meliputi yaitu triangulasi sumber dan triangulasi metode. Triangulasi sumber dilakukan dengan observasi terhadap subyek penelitian yaitu siswa kelas II-b MIN Paya Bujok dan kolaborasi dengan guru kelas yang mengajar bidang studi akidah akhlak. Triangulasi metode dilakukan dengan penggunaan metode dokumentasi

Analisis data yang digunakan dalam penelitian ini adalah teknik analisis deskriptif yang meliputi :

AT-TARBAWI Media Pendidikan, Sosial dan Kebudayaan 
3. Analisis Deskriptif Komparatif, hasil belajar dengan cara membandingkan hasil belajar pada siklus I, II dan membandingkan hasil belajar dengan indikator pada siklus I, II .

4. Analisis Deskriptif Kualitatif, hasil observasi dengan cara membandingkan hasil observasi dan refleksi pada siklus I, II .

Menurut Milas (1992: 16) data yang sudah terkumpul dianalisis dengan mempedomani langkah-langkah analisis data penelitian kualitatif, analisis berlangsung dengan tiga jalur kegiatan yang terjadi secara bersamaan yaitu:

4. Reduksi data, yaitu meliputi proses penyeleksian, pemilihan, penyederhanaan dan pengkatagorian data, menganalisis dan penarikan kesimpulan.

5. Pengujian data, yaitu dengan mendeskripsikan apa yang terjadi

6. Penarikan kesimpulan yang dilakukan sejak tahap pengumpulan data dengan cara mencatat pada buku penelitian.

Analisis data dilakukan dalam hal sebagai berikut:

1. Aktivitas siswa selama pembelajaran. Menurut Arikunto (1996: 65) analisis data dilakukan mencari rata-rata :

2. Hasil observasi dan penyelesaian soal, dengan rumus sebagai berikut :

$$
\text { Persentasi siswa aktif }=\frac{\text { jumlah siswa aktif }}{\text { jumlah siswa keseluruhan }} \times 100 \%
$$

Ketuntasan

Ketuntasan

$$
\begin{aligned}
& \text { perorangan }=\frac{\text { jumlah skor yang diperoleh }}{\text { jumlah skor maksimal }} \times 100 \% \\
& \text { klasikal }=\frac{\text { jumlah siswa tuntas }}{\text { jumlah siswa keseluruhan }} \times 100 \%
\end{aligned}
$$

3. Analisis nilai persiswa setiap akhir siklus, menurut Arikunto (1996:250) perlu dilakukan analisis secara perorangan, yaitu membandingkan dengan nilai sebelumnya apakah nilainya naik atau menurun atau tetap. Meskipun siswa belum mencapai skor 70, tetapi sudah ada peningkatan nilai maka pemberian tindakan sudah menunjukkan hasil yang positif. Berdasarkan pendapat ini maka standar yang peneliti pakai adalah 70 . 
Berdasarkan analisis diatas dapat ditarik kesimpulan, apabila siswa telah dapat menguasai materi dari materi Akhlak Terpuji maka dapat dikatakan penelitian telah berhasil, dan penelitian dinyatakan selesai.

Tetapi jika ditemukan belum adanya perbaikan maka dilakukan diskusi dengan teman sejawat dan refleksi, untuk menemukan kelemahan dan kekurangan, selanjutnya dilakukan perbaikan yang dilakukan pada siklus ke II.

Dalam penelitian ini yang akan dilihat indikator kinerjanya. Dan indikator yang diharapkan dalam penelitian tindakan kelas ini adalah:

1. Terjadi peningkatan hasil belajar siswa dan mencapai ketuntasan belajar $=80$.

2. Terjadi peningkatan aktivitas belajar siswa pada setiap siklus.

3. Terjadi peningkatan pelaksanaan proses belajar mengajar yang diselenggarakan oleh guru

Prosedur penelitian terdiri dari 4 tahap, yakni perencanaan, melakukan tindakan, observasi, dan evaluasi. Penelitian ini akan di laksanakan dalam 2 siklus, setiap siklus nya dua kali pertemuan:

\section{Pembahasan Siklus I}

\section{Pertemuan pertama (3 September 2015 )}

1. Perencanaan

Identifikasi masalah dan penetapan alternatif pemecahan masalah.

- Merencanakan pembelajaran yang akan diterapkan dalam proses belajar mengajar.

- Menetapkan standar kompetensi dan kompetensi dasar.

- Memilih bahan pelajaran yang sesuai

- Menentukan skenario pembelajaran dengan pendekatan metode diskusi

- Mempersiapkan sumber, bahan, dan alat bantu yang dibutuhkan.

- Menyusun lembar kerja siswa

- Mengembangkan format evaluasi

- Mengembangkan format observasi pembelajaran.

2. Tindakan

- Menerapkan tindakan yang mengacu pada skenario pembelajaran.

- Siswa membaca materi yang terdapat pada buku sumber. 
- Siswa mendengarkan penjelasan guru tentang materi yang terdapat pada buku sumber.

- Siswa mendengarkan penjelasan guru tentang materi yang dipelajari.

- Siswa berdiskusi membahas masalah (kasus) yang sudah dipersiapkan oleh guru.

- Masing-masing kelompok melaporkan hasil diskusi.

- Siswa mengerjakan Lembar Kerja Siswa (LKS).

3. Pengamatan

- Melakukan observasi dengan memakai format observasi yang sudah disiapkan yaitu dengan catatan angket untuk mengumpulkan data.

- Melalui hasil tindakan dengan menggunakan format lembar kerja siswa (LKS).

4. Refleksi

- Melakukan evaluasi tindakan yang telah dilakukan meliputi evaluasai mutu, jumlah dan waktu dari setiap macam tindakan.

- Melakukan pertemuan untuk membahas hasil evaluasi tentang skenario pembelajaran dan lembar kerja siswa.

- Memperbaiki pelaksanaan tindakan sesuai hasil evaluasi, untuk digunakan pada siklus berikutnya.

\section{Pertemuan Kedua (10 September 2015)}

1. Perencanaan

- Identifikasi masalah dan penetapan alternatif pemecahan masalah.

- Merencanakan pembelajaran yang akan diterapkan dalam proses belajar mengajar.

- Menetapkan standar kompetensi dan kompetensi dasar.

- Memilih bahan pelajaran yang sesuai

- Menentukan skenario pembelajaran dengan pendekatan metode diskusi

- Mempersiapkan sumber, bahan, dan alat bantu yang dibutuhkan.

- Menyusun lembar kerja siswa

- Mengembangkan format evaluasi

- Mengembangkan format observasi pembelajaran.

2. Tindakan

- Menerapkan tindakan yang mengacu pada skenario pembelajaran. 
- Siswa membaca materi yang terdapat pada buku sumber.

- Siswa mendengarkan penjelasan guru tentang materi yang terdapat pada buku sumber.

- Siswa mendengarkan penjelasan guru tentang materi yang dipelajari.

- Siswa berdiskusi membahas masalah (kasus) yang sudah dipersiapkan oleh guru.

- Masing-masing kelompok melaporkan hasil diskusi.

- Siswa mengerjakan Lembar Kerja Siswa (LKS).

5. Pengamatan

- Melakukan observasi dengan memakai format observasi yang sudah disiapkan yaitu dengan catatan angket untuk mengumpulkan data.

- Menilai hasil tindakan dengan menggunakan format lembar kerja siswa (LKS).

4. Refleksi

- Melakukan evaluasi tindakan yang telah dilakukan meliputi evaluasai mutu, jumlah dan waktu dari setiap macam tindakan.

- Melakukan pertemuan untuk membahas hasil evalusi tentang skenario pembelajaran dan lembar kerja siswa.

- Memperbaiki pelaksanaan tindakan sesuai hasil evaluasi, untuk digunakan pada siklus berikutnya.

\section{Pembahasan Siklus II}

\section{Pertemuan I (17 September 2015)}

a. Perencanaan

- Identifikasi masalah yang muncul pada siklus I dan belum teratasi dan penetapan alternatif pemecahan masalah.

- Menentukan indikator pencapaian hasil belajar.

- Pengembangan program tindakan II.

b. Tindakan

Pelaksanaan program tindakan II yang mengacu pada identifikasi masalah yang muncul pada siklus I, sesuai dengan alternatif pemecahan masalah yang sudah ditentukan, antara lain melalui:

- Guru melakukan apersepsi

- Siswa yang diperkenalkan dengan materi yang akan dibahas dan tujuan yang ingin dicapai dalam pembelajaran. 
- Siswa mengamati permasalahan yang sesuai dengan materi.

- Siswa berdiskusi tentang permasalahan yang ada.

- Siswa membahas tentang materi yang di berikan oleh guru bersama temantemannya.

- Siswa mengumpulkan bacaaan dari berbagai sumber, melakukan diskusi kelompok belajar, memahami materi dan menulis hasil diskusi untuk dilaporkan.

- Presentasi hasil diskusi.

- Siswa menyelesaikan tugas pada Lembar Kerja Siswa (LKS).

c. Pengamatan (Observasi)

- Melakukan observasi sesuai dengan format yang sudah disiapkan dan mencatat semua hal-hal yang diperlukan yang terjadi selama pelaksanaan tindakan berlangsung.

- Menilai hasil tindakan sesuai dengan format yang sudah dikembangkan

d. Refleksi

- Melakukan evaluasi terhadap tindakan pada siklus II berdasarkan data yang terkumpul.

- Membahas hasil evaluasi tentang skenario pembelajaran pada siklus II.

- Memperbaiki pelaksanaan tindakan sesuai dengan hasil evaluasi untuk digunakan pada siklus III

- Evaluasi tindakan II

- Indikator keberhasilan yang dicapai pada siklus ini diharapkan mengalami kemajuan minimal 10\% dari siklus I.

\section{Pertemuan II ( 1 Oktober 2015)}

1) Perencanaan

- Identifikasi masalah yang muncul pada siklus II dan belum teratasi dan penetapan alternatif pemecahan masalah.

- Menentukan indikator pencapaian hasil belajar.

- Pengembangan program tindakan III.

2) Tindakan 
Pelaksanaan program tindakan III yang mengacu pada identifikasi masalah yang muncul pada siklus II, sesuai dengan alternatif pemecahan masalah yang sudah ditentukan, antara lain melalui:

- Guru melakukan apersepsi

- Siswa yang diperkenalkan dengan materi yang akan dibahas dan tujuan yang ingin dicapai dalam pembelajaran.

- Siswa mengamati permasalahan yang sesuai dengan materi.

- Siswa berdiskusi tentang permasalahan yang ada.

- Siswa membahas materi Akhlak Terpuji bersama teman-temannya.

- Siswa mengumpulkan bacaaan dari berbagai sumber, melakukan diskusi kelompok belajar, memahami materi dan menulis hasil diskusi untuk dilaporkan.

- Presentasi hasil diskusi.

- Siswa menyelesaikan tugas pada lembar kerja siswa.

3) Pengamatan (Observasi)

- Melakukan observasi sesuai dengan format yang sudah disiapkan dan mencatat semua hal-hal yang diperlukan yang terjadi selama pelaksanaan tindakan berlangsung.

- Menilai hasil tindakan sesuai dengan format yang sudah dikembangkan.

4) Refleksi

- Melakukan evaluasi terhadap tindakan pada siklus II berdasarkan data yang terkumpul.

- Membahas hasil evaluasi tentang skenario pembelajaran pada siklus II.

- Memperbaiki pelaksanaan tindakan sesuai dengan hasil evaluasi tindakan II.

- Indikator keberhasilan yang dicapai pada siklus ini diharapkan mengalami kemajuan minimal $9 \%$ dari siklus I.

Kriteria keberhasilan penelitian ini dari sisi proses dan hasil. Sisi proses yaitu dengan berhasilnya siswa memecahkan masalah melalui metode diskusi dengan mengadakan diskusi kelompok belajar, dimana para siswa dilatih untuk berani mengeluarkan pendapat dan/atau berbeda pendapat tentang materi yang di berikan.

\section{Kesimpulan}


Pembelajaran sebelum pelaksanaan tindakan kelas guru mengajar secara konvensional. Guru cenderung mentransper ilmu kepada siswa, sehingga siswa hanya mendengar dan siswa kurang aktif bahkan cenderung bosan. Proses pembelajaran tampak kaku karena siswa hanya melihat dan mendengar apa yang dijelaskan gurunya. Itu semua berdampak pada hasil nilai siswa di kelas II-b MIN Paya Bujok. Hal ini diindikasikan nilai hasil belajar dibawah kriteria ketuntasan minimal (KKM) sebesar 70 Deskripsi Siklus I

Tahap perencanaan pada siklus I dihasilkan beberapa perangkat pembelajaran dan instrumen penelitian. Perangkat pembelajaran yang dihasilkan adalah Rencana Pembelajaran (RPP), Buku Guru dan buku siswa. Adapun materi yang dibahas dalam perangkat pembelajaran tersebut.

Langkah-langkah pembelajaran yang disusun dalam RPP didesain sesuai dengan langkahlangkah pada metode diskusi . Buku siswa yang disusun merupakan kumpulan lembar ahli berupa uraian materi dari topic-topik yang dibahas. Sedangkan buku guru merupakan panduan bagi guru selama proses pembelajaran.

Hasil dari belajar siswa pada pertemuan pertama dan kedua dapat dideskripsikan pada tabel sebagai berikut :

Pertemuan 1

Nilai hasil belajar pada pertemuan I dapat dilihat pada tabel 1 sebagai berikut :

Tabel 1. Nilai Hasil Belajar Pertemuan I

\begin{tabular}{|l|l|l|l|l|l|}
\hline No & $\begin{array}{l}\text { Hasil } \\
\text { (angka) }\end{array}$ & Hasil (huruf) & Arti Lambang & $\begin{array}{l}\text { Jumlah } \\
\text { Siswa }\end{array}$ & Persen \\
\hline 1 & $85-100$ & A & Sangat baik & 0 & \\
\hline 2 & $75-84$ & B & Baik & 2 & \\
\hline 3 & $65-74$ & C & Cukup & 7 & $19,44 \%$ \\
\hline 4 & $55-64$ & D & Kurang & 9 & $25,00 \%$ \\
\hline 5 & $<54$ & E & Sangat kurang & 18 & $50,00 \%$ \\
\hline Jumlah & & & $\mathbf{3 6}$ & $\mathbf{9 4 \%}$ \\
\hline
\end{tabular}


Berdasarkan tabel 1 diperoleh 2 siswa mendapatkan nilai B, 7 siswa (19,44\%) mendapatkan nilai C, 9 siswa $(25,00 \%)$ mendapatkan nilai D, selebihnya yaitu 18 siswa (50,00\%) mendapatkan nilai E.

b) Pertemuan 2

Nilai hasil belajar pada pertemuan II dapat dilihat pada tabel 2 sebagai berikut :

Tabel 2. Nilai Hasil Belajar Pertemuan II

\begin{tabular}{|r|l|l|c|l|l|}
\hline No & $\begin{array}{l}\text { Hasil } \\
\text { (angka) }\end{array}$ & Hasil (huruf) & Arti Lambang & $\begin{array}{l}\text { Jumlah } \\
\text { Siswa }\end{array}$ & Persen \\
\hline 1 & $85-100$ & A & Sangat baik & 2 & - \\
\hline 2 & $75-84$ & B & Baik & 3 & $8,33 \%$ \\
\hline 3 & $65-74$ & C & Cukup & 10 & $27,78 \%$ \\
\hline 4 & $55-64$ & D & Kurang & 11 & $30,56 \%$ \\
\hline 5 & $<54$ & E & Sangat kurang & 10 & $27,7 \%$ \\
\hline Jumlah & & & $\mathbf{3 6}$ & $\mathbf{9 4 \%}$ \\
\hline
\end{tabular}

Berdasarkan tabel 2. diperoleh 2 siswa $(0.00 \%)$ mendapatkan nilai A, 3 siswa (8,33\%) mendapatkan nilai B, 10 siswa $(27,78 \%)$ mendapatkan nilai C, 11 Siswa (30,56\%) sisiwa yang mendapatkan nilai D, dan $10(27,7 \%$ ) siswa yang mendapat nilai E.

Berdasarkan hasil test kemampuan siswa siklus I dapat dijabarkan hal-hal sebagai berikut

- Pada pertemuan I diperoleh 6 siswa $(17, \%)$ tuntas dan 30 siswa (83\%) tidak tuntas dengan nilai rata rata 51,81

Tabel 3. ketuntasan siswa pertemuan pertama siklus I

\begin{tabular}{|l|l|l|l|}
\hline \multirow{2}{*}{ No } & \multirow{2}{*}{ Ketuntasan } & Jumlah siswa \\
\cline { 3 - 4 } & & Jumlah & Persen \\
\hline 1 & Tuntas & 6 & 17 \\
\hline 2 & Belum tuntas & 30 & 83 \\
\hline Jumlah & & 36 & 94 \\
\hline
\end{tabular}

- Pada pertemuan II mengalami peningkatan yaitu 10 siswa (27.78\%) tuntas, dan

- 26 siswa $(72,22 \%)$ tidak tuntas. Dengan nilai rata rata 57,86

AT-TARBAWI Media Pendidikan, Sosial dan Kebudayaan 
Tabel 4. ketuntasan siswa pertemuan kedua siklus I

\begin{tabular}{|l|l|l|l|}
\hline \multirow{2}{*}{ No } & \multirow{2}{*}{ Ketuntasan } & Jumlah siswa \\
\cline { 3 - 4 } & & Jumlah & Persen \\
\hline 1 & Tuntas & 10 & 27,78 \\
\hline 2 & Belum tuntas & 26 & 72,22 \\
\hline Jumlah & & 34 & 100 \\
\hline
\end{tabular}

- Nilai yang diperoleh masih belum sesuai dengan keinginan hal ini terjadi karena siswa masih belum optimal dalam bekerja sama namun aktivitas siswa sudah mulai membaik pada pertemuan ke II.

- Karena respons siswa sudah baik maka perangkat pembelajaran dan instrumen yang digunakan pada siklus II tetap sama seperti di siklus I.

Berdasarkan hasil pada siklus I maka pelaksanaan tindakan pada siklus II dapat didefenisikan sebagai berikut :

\section{Perencanaan Tindakan}

Seperti halnya pada siklus I, tahap perencanaan pada siklus II ini dihasilkan perangkat pembelajaran berupa RP, Buku Siswa, Buku Guru dengan menggunakan metode diskusi kelompok Sedangkan instrumen yang digunakan sama dengan pada siklus I, yaitu lembar test tertulis, lembar observasi dan dokumen siswa

\section{Pelaksanaan Tindakan Siklus II}

Tahap ini merupakan pelaksanaan dari RP yang sudah didesain sesuai dengan metode diskusi dengan skenario yang sama pada siklus I. Pada siklus ini walau mereka bekerja dengan kelompok masing-masing. Dalam hal ini terlihat secara langsung situasi belajar yang aktif, kreatif, antusias siswa dalam belajar dan memperhatikan serta menyampaikan hasil kerjanya sangat baik, hampir seluruh kelompok mampu menguasai dan aktif dalam proses pembelajaran tersebut.

\section{Hasil Pengamatan (Observasi)}

Pelaksanaan observasi pada kegiatan siklus II sama dengan kegiatan pada siklus I. Dalam hal ini observasi dilakukan oleh teman sejawat yaitu guru sebagai observer. Observasi dilakukan untuk mengetahui keaktifan siswa, kerjasama, kecepatan dan ketepatan siswa dalam memahami materi. 
Hasil pengamatan pada siklus II dapat dideskripsikan sebagai berikut ::

a) Pertemuan 1

Nilai hasil belajar pada pertemuan I dapat dilihat pada tabel sebagai berikut :

Tabel 1 Nilai Hasil Belajar Pertemuan I

\begin{tabular}{|l|l|l|l|l|l|}
\hline No & $\begin{array}{l}\text { Hasil } \\
\text { (angka) }\end{array}$ & Hasil (huruf) & Arti Lambang & $\begin{array}{l}\text { Jumlah } \\
\text { Siswa }\end{array}$ & Persen \\
\hline 1 & $85-100$ & A & Sangat baik & 0 & $0,00 \%$ \\
\hline 2 & $75-84$ & B & Baik & 15 & $41,67 \%$ \\
\hline 3 & $65-74$ & C & Cukup & 14 & $38,89 \%$ \\
\hline 4 & $55-64$ & D & Kurang & 5 & $13,89 \%$ \\
\hline 5 & K54 & E & Sangat kurang & 2 & $5,56 \%$ \\
\hline Jumlah & & 36 & $100 \%$ \\
\hline
\end{tabular}

Berdasarkan tabel diperoleh 15 siswa (41.67\%) mendapatkan nilai B, 14 siswa (38.89\%) mendapatkan nilai C, dan 5 siswa (13.89\%) mendapatkan nilai D,dan 2 siswa (5,56\%) mendapat nilai E.

b) Pertemuan 2

Nilai hasil belajar pada pertemuan II dapat dilihat pada tabel sebagai berikut :

Tabel 1 Nilai Hasil Belajar Pertemuan II

\begin{tabular}{|l|l|l|l|l|l|}
\hline No & $\begin{array}{l}\text { Hasil } \\
\text { (angka) }\end{array}$ & $\begin{array}{l}\text { Hasil } \\
\text { (huruf) }\end{array}$ & Arti Lambang & $\begin{array}{l}\text { Jumlah } \\
\text { Siswa }\end{array}$ & Persen \\
\hline 1 & $85-100$ & A & Sangat baik & 5 & $13,89 \%$ \\
\hline 2 & $75-84$ & B & Baik & 25 & $69,44 \%$ \\
\hline 3 & $65-74$ & C & Cukup & 5 & $13,89 \%$ \\
\hline 4 & $55-64$ & D & Kurang & 1 & $2,78 \%$ \\
\hline
\end{tabular}




\begin{tabular}{|l|l|l|l|l|}
\hline & $<54$ & Sangat kurang & 0 & $0,00 \%$ \\
\hline Jumlah & $\mathbf{3 6}$ & $\mathbf{1 0 0 \%}$ \\
\hline
\end{tabular}

Berdasarkan tabel diatas diperoleh 5 siswa (13.89\%) mendapatkan nilai A, 25 siswa (69.44\%) mendapatkan nilai B, 5 siswa (13.89\%) mendapatkan nilai C,dan 1 siswa (2,78\%) mendapatkan nilai D.

Berdasarkan hasil test kemampuan siswa siklus II dapat dijabarkan sebagai berikut :

- Pertemuan I diperoleh 26 siswa (72,22\%) tuntas, dan 10 siswa (27.78\%) tidak tuntas, dengan nilai rata-rata 70.06 .

Tabel 2 jumlah ketuntasan siswa pertemuan pertama siklus II

\begin{tabular}{|l|l|l|l|}
\hline \multirow{2}{*}{ No } & \multirow{2}{*}{ Ketuntasan } & Jumlah siswa \\
\cline { 3 - 4 } & & Jumlah & Persen \\
\hline 1 & Tuntas & 26 & 72.22 \\
\hline 2 & Belum tuntas & 10 & 27.78 \\
\hline Jumlah & & 36 & 100 \\
\hline
\end{tabular}

- Pertemuan II mengalami peningkatan yaitu 29 siswa (85,59\%) tuntas, selebihnya 5 siswa $(14,71 \%)$ yang tidak tuntas, dengan nilai rata-rata 76.00 .

Tabel ketuntasan siswa pertemuan kedua siklus II

\begin{tabular}{|l|l|l|l|}
\hline \multirow{2}{*}{ No } & \multirow{2}{*}{ Ketuntasan } & Jumlah siswa \\
\cline { 3 - 4 } & & Jumlah & Persen \\
\hline 1 & Tuntas & 34 & 94.44 \\
\hline 2 & & 2 & 5.56 \\
\hline Jumlah & Belum tuntas & 36 & 100 \\
\hline
\end{tabular}

- Maka diperoleh selisih nilai rata-rata siswa antara pertemuan I dan II sebesar 76.78. - Dapat dikatakan hasil belajar siswa sudah baik karena ada peningkatan hal ini menunjukkan perubahan langkah pembelajaran yang digunakan oleh guru cukup efektif dalam memotivasi siswa.

82 
- Tingkat kinerja aktivitas guru semakin baik, walaupun masih ada beberapa kekurangan. Misalnya cara mengajukan pertanyaan dan membimbing siswa dalam materi Akhlak Terpuji.

\section{Daftar Pustaka}

Departemen Agama RI/Direktorat Jendral, Pembinaan Kelembagaan Islam.

Eman Suherman dan Udin S.Winatapura, Materi Pokok Strategi Mengajar, Jakarta :Depdikbut,1993.

. Holstein, Murid Belajar Mandiri, Bandung :Remaja Karya, 1989.

I.G.A,K. Wardani, Kuswaya W, Noehi Nasoetion, Penelitian Tindakan Kelas, Jakarta :Universitas Terbuka,1987.

Syaodih, Nana, Metode Penelitian Pendidikan, Bandung :Rosda, 2005.

Sunardi, Mengakrabkan Agama pada Anak, Yogyakarta :Kedaulatan Rakyat, 2006.

Wagiman, Setiyandoko, dkk, Belajar dan Bermain untuk SD/MI Kelas 5, Malang : Universitas Negeri Malang, 2005. 